\title{
Effectiveness Of Relationship Marketing Tactics In A University Setting
}

Philip J. Trocchia, University of South Florida St. Petersburg, USA

R. Zachary Finney, University of South Alabama, USA

Treena Gillespie Finney, University of South Alabama, USA

\begin{abstract}
We test the correlation between student perception of three university relationship-building tactics - commercial friendships, preferential treatment, and tangible rewards - with university student satisfaction. We also test whether two student characteristics - enduring involvement with education and sense of entitlement - have a moderating effect on the aforementioned relationship between university relationship-building behaviors and student satisfaction. Results revealed positive correlations between perceived relationship tactics and overall satisfaction. Correlations between the relationship-building behaviors and satisfaction were also greater among highinvolvement students than among their lesser-involved cohorts. Students who felt a sense of entitlement were more likely to believe that they were recipients of relationship-building behaviors, but they didn't always appreciate them more than students who felt less entitled.
\end{abstract}

Keywords: Student Entitlement; Relationship Marketing; Education; Student-Teacher Interaction

\section{INTRODUCTION}

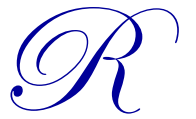

elationship Marketing (RM) is a paradigm dating back nearly three decades (Aijo, 1996; Berry, 1983; Gronroos, 1994; Williams, 2012). Instead of focusing on discrete transactions, firms practicing relationship marketing emphasize building longer-term relationships with their customers. This emphasis helps to foster customer loyalty, which facilitates a stable, mutually profitable, and long-term relationship between the firm and its clientele.

Some critics contend that the relationship marketing concept offered little to differentiate it from alreadyestablished schemes and it merely devised new terms for practices in which firms had been engaging for years (Petrof, 1997). Other skeptics contend that, in practice, RM benefits the firm rather than the customer. For the customer, RM programs result in pressures to provide personal information to firms with few measurable benefits. These skeptics point out that, in spite of RM, many customers are still dissatisfied with the relationships they have with businesses (Fournier, Dobscha, and Mick, 1998; Ritter and Walter, 2012).

Research indicates that RM is not appropriate for all types of consumption. Dowling (2002) found that for low-involvement products, product availability, customer habit, and customer knowledge were more relevant in explaining consumer decision-making than were relationships. On the other hand, scholars have identified many instances in which consumers prefer relationships, particularly when dealing with salespeople (c.f. Berry and Parasuraman, 1991; Parasuraman, Berry, and Zeithaml, 1991). Such findings demonstrate that we are moving toward a better understanding of the circumstances under which firms should adopt relationship marketing tactics.

Are such tactics appropriate for higher education? Scholars have extensively examined RM in consumer goods and services contexts (c.f. Garbarino and Johnson, 1999; Parish and Holloway, 2010), as well as in businessto-business situations (Pinnington and Scanlon, 2009; Watkins and Hill, 2009). However, researchers have paid only scant attention to RM in an educational context (c.f. Seeman and O'Hara, 2006). Universities want their students to attend classes regularly, graduate, and extend the school-student relationship well beyond the commencement ceremony by contributing to their alma maters as successful alumni (Heckman and Guskey, 1998). Universities also 
desire good relationships with their students; alumni who feel a bond with their alma mater are likely to generate and spread positive word-of-mouth about their university to their friends, families, and employers.

Although we would like to think that investing in relationship-building behaviors would always result in across-the-board dividends in terms of improved university-student relationships, we know that such linearity of input to output is rarely the case. As a result, besides analyzing the effect that relationship building behaviors have on student satisfaction, we also look at the role that certain variables (in this case, student involvement and student entitlement) play in potentially moderating the relationship between relationship-building tactics and student satisfaction.

In this article, we examine three types of "relationship investments." Scholars have studied these types of relationships in consumer settings but have largely ignored their implications for educational services. Berry (1995) describes three levels of relationship marketing. Level one, considered the weakest in the hierarchy, relies on financial incentives to retain customers. Level two focuses on creating and maintaining social bonds between a firm and its customers. Level three allows businesses to use technology (e.g. customer database software) to create and enhance ties with their clients.

Just as manufacturers and retailers use relationship marketing tactics to gain customer loyalty, university faculty, staff, and administrators may use such relationship-building approaches in order to achieve student satisfaction and foster attitudinal and behavioral loyalty.

Here we investigate three types of relationship marketing tactics that universities may use to develop and maintain bonds with students. The first two that we discuss - commercial friendships and preferential treatment may be best classified as Level two relationships since they emphasize personal bonds. The third category, tangible rewards, essentially fits the definition of a Level one relationship-building mechanism as it is based on monetary remuneration. Below we elaborate on our student satisfaction measure and then we describe the three relationship investment mechanisms.

\section{Satisfaction with University}

Researchers studying close relationships find that dissatisfied people disengage from and neglect their obligations to the other party with whom they are dissatisfied (Rusbult, Zembrodt, \& Gunn, 1982). Consumers who become dissatisfied respond through voice (e.g., stating discontent) and exit (completely departing the situation), but some unhappy consumers also show loyalty; for instance, by remaining in the situation while hoping it improves (Hirschman, 1970). We therefore expect satisfied students to be more engaged in university affairs and to be less likely to complain and more likely to graduate than dissatisfied students.

We adapted the satisfaction scale from Halstead, Hartman, and Schmidt's (1994) satisfaction measure. We used three seven-point Likert Scale items describing students' attitudes and behavioral intentions regarding their choice of higher educational institution. Specific questions measured students' views about whether they would advise others to attend their university, whether they would choose to attend the university if they had it to do "all over again," and their views on whether their decision to attend the school was wise.

\section{Commercial Friendship}

People in high customer contact jobs often form commercial friendships with their customers. Examples include bartenders (Cowen 1982), hair stylists (Price and Arnould, 1999) and river rafting tour guides (Arnould and Price, 1993). An employee may see commercial friendships as a means to an end (e.g., an employee hopes to get a large tip or a gift in exchange for good service). Some people, however, are basically altruistic and enjoy the chance to help customers. In universities, commercial friendships exist when students perceive that faculty take time and effort to get to know them individually through friendly interactions.

Hypothesis 1a: There will be a positive correlation between students' perceptions of commercial friendships with university staff and their level of satisfaction with the university. 


\section{Preferential Treatment}

DeWulf, Odekerken-Schroder, and Iacobucci (2001) define preferential treatment in the context of relationship marketing as 'a consumer's perception of the extent to which a retailer treats and serves its regular customers better than its non-regular customers' (p. 35). In the educational setting, we define preferential treatment as a student's perception that faculty exert more positive effort toward them than they do toward other students. As such, we adapted items from DeWulf, et al (2001) in order to fit within the context of education.

Hypothesis 1b: There will be a positive correlation between students' perceptions of preferential treatment and their level of satisfaction with the university.

\section{Tangible Rewards}

DeWulf, et al's (2001) concept of tangible rewards was that customers 'receive something tangible in return for their loyalty' (p. 36). Similarly, we define tangible rewards as the student's perception that the school offered some monetary incentives as a reward for enrolling in and attending the institution.

Hypothesis 1c: There will be a positive correlation between students' perceptions of tangible rewards and their level of satisfaction with the university.

\section{Enduring Involvement as a Moderator of Perceived Relationship Investment}

This paper also assesses the role that involvement plays in moderating the link between the aforementioned relationship-building behaviors and student satisfaction. Consumer involvement, at its fundamental level, pertains to a person's interest in a particular activity, product, or context (Decloe, Kaczynski, and Havitz, 2009). Enduring involvement (EI) reflects a particularly strong attraction that some consumers have in regard to a product class. High EI consumers "focus their time, energy, and resources intently on a specific area of interest" (Thorne and Bruner, 2006). Scholars find that involved students are more likely to be successful (Fritschner, 2000; Howard \& Henney, 1998; Tinto, 1997). This reflects the interest and excitement some product classes engender, in particular, individuals (Flynn and Goldsmith, 1993).

The role of involvement is important because the university's investment in terms of time and money will probably not yield similar returns for all students; scholars suggest that relationships can add value for customers who truly value the product (Dick and Basu, 1994). In other words, we would expect customers who enjoy cooking to be more responsive to a business that offered recipes, cooking tips, and food coupons than would those who are less interested in cooking. Likewise, we expect that students who are more involved with education will be more responsive toward friendships, preferential treatment, and tangible rewards associated with higher education.

Hypothesis 2a: The impact of commercial friendship behaviors on highly involved students' satisfaction with the university will be greater than the impact that commercial friendship behaviors have on students with lower levels of involvement.

Hypothesis 2b: The impact of preferential treatment on highly involved students' satisfaction with the university will be greater than the impact that preferential treatment has on students with lower levels of involvement.

Hypotheses 2c: The impact of tangible rewards on highly involved students' satisfaction with the university will be greater than the impact that tangible rewards have on students with lower levels of involvement.

\section{Entitlement}

The entitlement construct was used because of the considerable attention that student entitlement has received in recent years in the academic literature and the popular press (c.f. Greenberger, Lessard, Chen, and Farruggia, 2008; Marsden, 2009), as well as in informal discourse among academics. It is difficult to generalize about differences in the attitudes of contemporary college students, vis-à-vis the attitudes of students in prior 
generations. However, anecdotal evidence implies today's students have a stronger sense of entitlement (Trzesniewski, Donnellan, \& Robins, 2008; Twenge, 2006) than previous ones. After all, as the nickname 'GenMe' implies, a sense of entitlement characterizes the most recent 'named' generation (those born between 1982 and 1999) and our current student population (Twenge, 2006; 2009). According to Twenge (2009), GenMe places a higher value on extrinsic rewards, such as high salary and vacation time, than did previous generations, but generally lacks a strong work ethic to achieve those benefits. That combination indicates a pervasive sense of entitlement among individuals in this group. The author asserts that those belonging to 'GenMe' tend to dislike working overtime; however, the fact that they still expect higher job status and salaries than previous generations reveals a chasm between their expectations and reality. These qualities reveal a sense of overconfidence and even narcissism.

In fact, one may view entitlement as a subcomponent of narcissism (Emmons, 1984). Entitlement refers to the extent to which a person expects special treatment and automatic compliance with his or her expectations (Boyd and Helms, 2005). For an entitled student, the grade he earns in a course (by demonstrating a particular knowledge of skill level) is irrelevant. Scholars contend that some entitled students attempt to earn grades by "bargaining" with faculty; other entitled individuals believe that faculty "provide" grades to students, much as faculty provide lectures and advice (Naumann, Minsky, \& Sturman, 2002).

Hence, we believe that an entitled student expects to receive exceptional levels of support from faculty and staff. Entitled students, moreover, will also be more willing to complain vociferously to the teacher or lodge complaints to administrators regarding any perceived classroom problem (Watson, Grisham, Trotter, and Biderman, 1984; Boyd and Helms, 2005). Because students who possess strong feelings of entitlement believe they deserve 'all the best things in the world' anyway, they simply expect such niceties as being friends with authority figures, preferential classroom treatment, and monetary rewards. We therefore predict they will be less impressed (and subsequently less satisfied) when relationship-investing behaviors are directed toward them than will students with lower senses of entitlement.

Hypothesis 3a: The impact of commercial friendship behaviors on highly entitled students' satisfaction with the university will be lower than the impact that commercial friendship behaviors have on students with lower levels of entitlement.

Hypothesis 3b: The impact of preferential treatment on highly entitled students' satisfaction with the university will be lower than the impact that preferential treatment has on students with lower levels of entitlement.

Hypothesis 3c: The impact of tangible rewards on highly entitled students' satisfaction with the university will be lower than the impact that tangible rewards have on students with lower levels of entitlement.

\section{METHOD}

\section{Participants}

One thousand two-hundred and twenty-six questionnaires were distributed to and collected from students at a medium-sized university in southeastern United States. The university's Institutional Review Board approved the study and survey. Before completing the questionnaire, students read a statement of informed consent and were asked three qualifying questions to ensure the respondent was a student at the sponsoring university, at least 19 years of age, and had not completed the questionnaire in another class. The questionnaire's instructions revealed only that the study would examine respondents' attitudes about their college experiences. We discarded any surveys in which more than ten percent of the items were blank. In order to ensure the validity of our research, we relied on established measures of the study's constructs. We sought multi-item measures that would allow for flexibility and sophistication in our data analyses. In addition to the scales, our instrument also included a set of demographic items. Reliabilities for all scales used in the study were high, ranging from .78 to .92 (Table 1). 
Table 1 Scale Reliabilities

\begin{tabular}{|l|c|}
\hline \multicolumn{1}{|c|}{ Construct } & Cronbach's Alpha \\
\hline Commercial Friendships & .85 \\
Preferential Treatment & .92 \\
Tangible Rewards & .86 \\
Satisfaction & .87 \\
Enduring Involvement with Education & .82 \\
Entitlement & .78 \\
\hline
\end{tabular}

\section{RESULTS}

First, it was no surprise that relationship-building behaviors had a significant impact on satisfaction with the university. Student satisfaction was positively correlated with perceived commercial friendships $(\mathrm{r}=.293$; $\mathrm{p} .<$ $.001)$, preferential treatment $(\mathrm{r}=.120 ; \mathrm{p}<.001)$, and tangible rewards $(\mathrm{r}=.201 ; \mathrm{p}<.001)$. It was somewhat surprising that, although the correlations were all strongly statistically significant, they were also somewhat weak, each lower than 0.3. H1a, H1b, and H1c were all supported.

In order to test whether enduring involvement impacts faculty relationship-building behaviors, students whose self-reported enduring involvement scores placed them in the lowest quartile, were compared with students in the highest quartile. Students scoring 22 or less out of a possible 35 (five summated seven-point scale items) placed in the lowest quartile $(n=305)$ while those scoring 31 or more $(n=295)$ were located in the highest quartile.

Predictably, satisfaction was greater among higher involvement students (mean = 16.0 on a 4-item, 5-point scale) than it was among relatively lower involvement students (mean $=12.8 ; \mathrm{p}<.001$ ). Also, highly involved students were more likely to indicate that their university engaged in the three relationship-building behaviors than were less-involved students (see Table 2a.)

Students were similarly separated by their entitlement scores. Highly-entitled students were those who scored 39 or above on the summated seven-item, seven-point entitlement scale, placing them in the highest quartile. Low-entitlement students were those scoring below 28 on the same scale, placing them in the lowest quartile. Highentitlement students were more likely to indicate that their university engaged in the three relationship-building behaviors than were the less-entitled students (see Table $2 b$ ).

Table 2a: Independent Sample T-Test Results for High versus Low Involvement Students' Perceptions of Relationship-building Behaviors

\begin{tabular}{|c|c|c|c|}
\hline Enduring Involvement & Commercial Friendships & Preferential Treatment & Tangible Rewards \\
\hline Low & 10.3 & 8.1 & 8.3 \\
\hline High & 11.8 & 9.6 & 10.3 \\
Sig. & .000 & .001 & .000 \\
\hline
\end{tabular}

Table 2b: Independent Sample T-Test Results for High versus Low Entitlement Students' Perceptions of Relationship-building Behaviors

\begin{tabular}{|c|c|c|c|}
\hline Entitlement & Commercial Friendships & Preferential Treatment & Tangible Rewards \\
\hline Low & 10.1 & 8.9 & 8.2 \\
\hline High & 12.1 & 9.9 & 9.5 \\
Sig. & .000 & .006 & .002 \\
\hline
\end{tabular}

Among the relatively low-involvement students, the correlation between satisfaction and commercial friendship was, somewhat surprisingly, significant $(\mathrm{p}<.001)$ at .218 . Among the high involvement students, the correlation coefficient was higher - at $.321(\mathrm{p}<.01)$. In terms of preferential treatment, the results reveal virtually no correlation between preferential treatment and satisfaction among the low-involvement students in the sample. However, among higher-involvement students, the correlation between preferential treatment and satisfaction was greater, at .174 , and significant $(\mathrm{p}=.004)$. Comparing the two groups, in terms of the final relationship-building construct, yielded somewhat similar results, with low involvement students achieving a .177 correlation between tangible rewards $(\mathrm{p}=.076)$ and satisfaction. High involvement students, on the other hand, generated a higher 
correlation between the same variables, at 296 ( $<$ .000). H2a was not supported. H2b and H2c were supported (see Table 3a).

Table 3a: Correlation Coefficients and Significance Levels

between Relationship-building Behaviors and Satisfaction under Conditions of High and Low Involvement

\begin{tabular}{|l|c|c|c|}
\hline \multicolumn{1}{|c|}{ Enduring Involvement } & Commercial Friendships & Preferential Treatment & Tangible Rewards \\
\hline Low & .218 & .013 & .177 \\
Correlation & $(.000)$ & $(.813)$ & $(.076)$ \\
(Significance) & & & .296 \\
High & .321 & .174 & $(.000)$ \\
\hline Correlation & $(.000)$ & $(.004)$ & \\
\hline
\end{tabular}

To test whether student feelings of entitlement affect their reactions to faculty relationship-building behaviors, students whose self-reported entitlement scores placed them in the bottom quartile were compared with students in the top quartile. Satisfaction with the university was greater among students feeling a greater sense of entitlement $($ mean $=16.1)$ than it was among those feeling less entitled (mean $=13.8 ; \mathrm{p}<.001)$. Also, means of the three relationship-building behaviors among high entitlement students were higher than for their less-entitled counterparts (see Table $2 b$ ).

Among students who feel a relatively low sense of entitlement, the correlation between satisfaction and commercial friendship was significant $(\mathrm{p}<.001)$ at .379 . Among students who felt a greater sense of entitlement, the correlation coefficient was also significant, although somewhat lower, at $.256(\mathrm{p}<.01)$. We found virtually no correlation between preferential treatment and satisfaction among the low-entitlement students in the sample $(\mathrm{p}=$ .341). However, among those feeling a greater sense of entitlement, the correlation between preferential treatment and satisfaction was significant, if somewhat weak, at $.151(\mathrm{p}=.01)$. Finally, for low-entitlement students, the relationship between tangible rewards and satisfaction was rather low $(\mathrm{r}=.128)$, but significant $(\mathrm{p}=.03)$. For students feeling a greater sense of entitlement, the correlation between tangible rewards and satisfaction was much greater - at .293 ( $\mathrm{p}$ <.001). H3a, H3b, and H3c were essentially unsupported (see Table 3b).

Table 3b: Correlation Coefficients and Significance Levels

between Relationship-building Behaviors and Satisfaction under Conditions of High and Low Entitlement

\begin{tabular}{|l|c|c|c|}
\hline \multicolumn{1}{|c|}{ Entitlement } & Commercial Friendships & Preferential Treatment & Tangible Rewards \\
\hline Low & .379 & .015 & .128 \\
$\begin{array}{l}\text { Correlation } \\
\text { (Significance) }\end{array}$ & $(.000)$ & $(.341)$ & $(.03)$ \\
\hline High & .256 & .151 & .293 \\
Correlation & $(.000)$ & $(.01)$ & $(.000)$ \\
(Significance) & & & \\
\hline
\end{tabular}

\section{DISCUSSION}

This paper demonstrated that level of student involvement in education does indeed have a significant impact on the effectiveness of relationship-building behaviors. One implication might be for university faculty and administrators to focus more of their efforts on those students who seem interested and involved in the educational process since the payoff for those less involved students will be considerably less. This appears to be a somewhat cynical approach, however. Another potential approach would attempt to make uninvolved students more involved. Students may be encouraged to see how knowledge acquisition and improved decision-making processes could serve as a conduit toward more promising futures.

In terms of the impact that entitlement has on the relationship between relationship-building behaviors and satisfaction, the results were more mixed. The commercial friendship relationship-building behavior was somewhat more effective for students with a low sense of entitlement than with a greater sense of entitlement. This makes sense as students who don't feel a great deal of self-confidence and narcissism may feel honored to obtain the 
friendship of an individual in an authority position. Conversely, those who already feel a sense of entitlement may simply feel that the professor's friendship is due them because of their elevated sense of self.

One limitation of the study was that, although there are three levels of relationship-building behaviors, only two were studied here. Level three relationship-building behaviors might be studied in the future so that we can test their effectiveness. Such behaviors may be somewhat controversial in an academic setting because they would clearly place the student in the driver's seat; that is, in the role of student as customer rather than as academic product (Finney and Finney, 2010). Tactics might include such niceties as recommending custom schedules based on pre-specified preferences (e.g., no morning classes, dorm room with western exposure, only wants instructors whose average GPA is above 3.0, etc.). Some universities, in an effort to increase satisfaction, enrollments, and tuition, may adopt such a model while others may be reluctant to do so, as this may be perceived as a sort of 'let the inmates run the prison' situation.

Overall, we believe the study provides an initial glimpse at the effectiveness that relationship-building tactics have on students. Universities may wish to expand on this research in an effort to decipher which tactics work best for their particular student body. Doing so might help build demand for the institution, allowing for higher tuition and revenues, admission of higher quality students, and perhaps even generate more support in the community and among the public at large.

\section{AUTHOR INFORMATION}

Philip J. Trocchia is Associate Professor of Marketing at the University of South Florida St. Petersburg. He earned his degree in marketing from the University of Alabama in 1997. Dr. Trocchia's research interests include marketing education, technology and marketing, and services marketing. His research appears in such journals as Psychology \& Marketing, European Journal of Marketing, Journal of Consumer Marketing, and Journal of Services Marketing. E-mail: philtrocchia@yahoo.com (Corresponding author)

R. Zachary Finney is Associate Professor of Marketing at the Mitchell College of Business at the University of South Alabama. He earned his PhD in marketing from the University of Alabama in 2001. Dr Finney's research has been accepted for publication in numerous journals including the Journal of Business Research, the Journal of Advertising Research, the Journal of Marketing Theory and Practice, and Marketing Management Journal. In 2003, Dr Finney and two colleagues won the Steven J. Shaw Award for the Outstanding Conference Paper at the Society for Marketing Advances Annual Conference in New Orleans. Dr Finney's primary area of scholarly research is marketing strategy. E-mail: zfinney@usouthal.edu

Treena Gillespie Finney is Associate Professor of Management at the Mitchell College of Business at the University of South Alabama. She earned her Ph.D. in Industrial/Organizational Psychology from DePaul University. Dr. Finney's research interests include international human resource management, performance appraisal and 360-degree feedback, and employee attitudes. Her research has appeared in such publications as the Journal of Management Education and Journal of Managerial Issues. E-mail: tgillespie@usouthal.edu

\section{REFERENCES}

1. Aijo, T.S. (1996). The theoretical and philosophical underpinnings of relationship marketing. European Journal of Marketing, 30(2), 8-18.

2. Arnould, E.J. \& Price, L.L. (1993, June). River magic: Extraordinary experience and the extended service encounter. Journal of Consumer Research, 20, 21-45.

3. Berry, L.L. (1983). Relationship Marketing, in L.L. Berry, G.L. Shostack, and G.D. Upah (eds.), Emerging Perspectives on Service Marketing (Chicago: American Marketing Association), pp. 25-28.

4. Berry, L.L. (1995). Relationship Marketing of Services - Growing Interest, Emerging Perspectives. Journal of the Academy of Marketing Sciences, 23(4), 236-45.

5. $\quad$ Berry, L.L., \& Parasuraman, A. (1991). Marketing Services: Competing Through Quality, New York: The Free Press. 
6. Boyd, H. C., \& Helms, J. (2005). Consumer entitlement theory and measurement. Psychology \& Marketing, 22(3), 271-286.

7. Casalo, L. V., Flavian, C., \& Guinaliu, M. (2008). The role of satisfaction and website usability in developing customer loyalty and positive word-of-mouth in the e-banking services. The International Journal of Bank Marketing, 26(6), 399-417.

8. Cowen, E.L. (1982). Help is where you find it: Four informal helping groups. American Psychologist, 37, 385-395.

9. $\quad$ Day, G.S. (1971). Attitude change, media, and word-of-mouth. Journal of Advertising Research, 11(6), 3140.

10. Decloe, M. D., Kaczynski, A.T., \& Havitz, M.E. (2009). Social participation, flow and situational involvement in recreational physical activity. Journal of Leisure Research, 41(1), 73-80.

11. De Wulf, K., Odekerken-Schroder, G., \& Iacobucci, D. (2001, October). Investments in consumer relationships: A cross-country and cross-industry exploration. Journal of Marketing, 65, 33-50.

12. Dichter, E. (1966). How word-of-mouth advertising works. Harvard Business Review, 44, 147-166.

13. Dick, A. S., \& Basu, K. (1994). Customer loyalty: Toward an integrated conceptual

14. Framework. Journal of the Academy of Marketing Science, 22(2), 99 - 113.

15. Dowling, G. (2002). Customer relationship management: In B2C markets, often less is more. California Management Review, 44(3): 87-104.

16. Emmons, R.A. (1984). Factor analysis and construct validity of the narcisistic personality inventory. Journal of Personality Assessment, 48, 291-300.

17. Finney, T.G., \& Finney, R.Z. (2010). Are students their universities' customers? An exploratory study. Education + Training 52 (4), 276 - 291.

18. Flynn, L.R., \& Goldsmith, R.E. (1993). A causal model of consumer involvement: Replication and critique. Journal of Social Behavior and Personality, 86(6), 129-42.

19. Fournier, S. (1998). Consumers and their brands: Developing relationship theory in consumer research. Journal of Consumer Research. 24(4); 343 - 373.

20. Fournier, S., Dobscha, S., \& Mick, D.G. (1998). Preventing the premature death of relationship marketing. Harvard Business Review, 76(1): 42-51.

21. Fritschner, L. M. (2000). Inside the undergraduate college classroom: Faculty and students differ on the meaning of student participation. Journal of Higher Education, 71, 342-362.

22. Garbarino, E. \& Johnson, M.S. (1999). The different roles of satisfaction, trust, and commitment in customer relationships, Journal of Marketing, 63(April), 70-87.

23. Greenberger, E., Lessard, J. Chen, C., \& Farruggia, S.P. (2008). Self-entitled college students: contributions of personality, parenting, and motivational factors. Journal of Youth and Adolescence, 37(10), 1193-1204.

24. Gronroos, C. (1994). From marketing mix to relationship marketing: Toward a paradigm shift in marketing. Management Decision, 32(2), 4-32.

25. Halstead, D., Hartman, D. \& Schmidt, S.L. (1994). multisource effects on the satisfaction formation process, Journal of the Academy of Marketing 22(2), 114-129.

26. Heckman, R., \& Guskey, A. (1998). The relationship between alumni and university: Toward a theory of discretionary collaborative behavior. Journal of Marketing Theory \& Practice, 6(2), 97-112.

27. Hirschman, A. O. (1970). Exit, voice and loyalty: Responses to decline in firms, organizations, and states. Cambridge, MA: Harvard University Press.

28. Hobbs, R., \& Rowley, J. (2008). Are pub discount cards loyalty cards? The Journal of Consumer Marketing, 25(6), $369-377$.

29. Howard, J. R., \& Henney, A. L. (1998). Student participation and instructor gender in the mixed-age college classroom. Journal of Higher Education, 69, 384-405.

30. Kozinets, R.V. (2002). The field behind the screen: Using netnography for marketing research in online communities. Journal of Marketing Research, 39(1), 61-72.

31. Marsden, R. (2009, December 31). Technology and the New 'Me' Generation. Wall Street Journal, (Eastern edition), A13.

32. Naumann, S. E., Minsky, B. D., \& Sturman, M. C. (2002). A historical examination of employee entitlement. Journal of Management History, 40(1), 89-94. 
33. Parasuraman, A., Berry, L.L., \& Zeithaml, V.A. (1991). Understanding customer expectations of service. Sloan Management Review, Spring, 39-48.

34. Parish, J. T., \& Holloway, B.B. (2010). Consumer relationship proneness: A re-examination and extension across service exchanges. The Journal of Service Marketing, 24(1), 61 - 73.

35. Petrof, J. V. (1997). Relationship marketing: The wheel reinvented? Business Horizons, 40(6): 26-31.

36. Pinnington, B. D., \& Scanlon, T. (2009). Antecedents of collective-value within business-to-business relationships. European Journal of Marketing, 43(1/2), 31 - 45.

37. Price, L.L. \& Arnould, E.J. (1999, October). Commercial friendships: service provider-client relationships in context. Journal of Marketing 63, 38-56.

38. Ritter, T., \& Walter, A. (2012). More is not always better: The impact of relationship functions on customer-perceived relationship value. Industrial Marketing Management, 41(1), 136 - 144.

39. Rusbult, C. E., Zembrodt, I. M., \& Gunn, L. K. (1982). Exit, voice, loyalty, and neglect: Responses to dissatisfaction in romantic involvements. Journal of Personality and Social Psychology, 43, 1230-1242.

40. Seeman, E., \& O’Hara, M. (2006). Customer relationship management in higher education. Campus-Wide Information Systems, 23(1), 24-34.

41. Thorne, S., \& Bruner, G.C. (2006). An exploratory investigation of the characteristics of consumer Fanaticism. Qualitative Market Research, 9(1), 51-72.

42. Tinto, V. (1997). Classrooms as communities: Exploring the essential character of student persistence. Journal of Higher Education, 68(6), 599-623.

43. Trzesniewski, K. H., Donnellan, M. B., \& Robins, R. W. (2008). Do today's young people really think they are so extraordinary? An examination of secular trends of narcissism and self-enhancement. Psychological Science, 19(2), 181-188.

44. Twenge, J. M. (2006). Generation Me: Why Today's Young Americans are More Confident, Assertive, Entitled - and More Miserable than Ever Before. NY: Free Press.

45. Twenge, J. M. (2009). The Narcissism Epidemic: Living in the Age of Entitlement. New York: Free Press.

46. Watkins, A., \& Hill, R.P. (2009). A simulation of business-to-business decision making in a relationship marketing context. Industrial Marketing Management, 33(8), 994- 1003

47. Watson, P.J., Grisham, S.O., Trotter, M.V., \& M.D. Biderman (1984). Narcissism and empathy: validity evidence for the narcisistic personality inventory. Journal of Personality Assessment, 48, 301-305.

48. Williams, K. (2012, May). Core qualities of successful marketing relationships, Journal of Management and Marketing Research, 10, 1-29. 
NOTES 